\title{
HUBUNGAN INTRAVESICAL PROSTATIC PROTRUSION DAN POST-VOID RESIDUAL URINE DENGAN LOWER URINARY TRACT SYMPTOMS PADA PASIEN KLINIS BENIGN PROSTATIC HYPERPLASIA TANPA RETENSI
}

\author{
THE RELATIONSHIP OF INTRAVESICAL PROSTATIC PROTRUSION AND POST- \\ VOID RESIDUAL URINE WITH LOWER URINARY TRACT SYMPTOMS ON BENIGN \\ PROSTATIC HYPERPLASIA WITHOUT RETENTION CLINICAL PATIENTS
}

\author{
Muhammad Eko Andaru, Wibisono, Suharto Wijanarko \\ Sub Bagian Bedah Urologi, Bagian Ilmu Bedah \\ FK UNS/RSUD Dr. Moewardi Surakarta \\ Korespondensi: dr. Muhammad Eko Andaru, Sp. B. Email: eko.andaru@gmail.com
}

\begin{abstract}
ABSTRAK
Benign prostatic hyperplasia (BPH) merupakan salah satu tumor jinak yang sering ditemukan pada pria usia lebih dari 50 tahun yang dapat menyebabkan lower urinary tract symptoms (LUTS). LUTS merupakan kumpulan gejala dari bladder outlet obstruction (BOO). Konfigurasi anatomi prostat berupa intravesical prostatic protrusion (IPP) telah terbukti memiliki korelasi yang baik untuk menyebabkan BOO. Peningkatan signifikan volume post-void residual urine (PVR) adalah manifestasi klinis yang sering terdapat pada pasien dengan BPH. Saat ini di RSDM, LUTS masih menjadi standar dalam menentukan tata laksana BPH. Berdasarkan uraian di atas peneliti tertarik untuk melakukan penelitian hubungan IPP dan PVR dengan LUTS pada pasien klinis BPH tanpa retensi. Penelitian ini merupakan studi observasional analitik dengan desain cross sectional. Sampel penelitian adalah pasien klinis BPH tanpa retensi yang datang ke poliklinik selama periode penelitian, kemudian dilakukan pemeriksaan transabdominal ultrasonography (TAUS) untuk mengukur IPP dan volume PVR serta menilai skor IPSS untuk menilai derajat LUTS. Analisis data hubungan antara IPP dan PVR terhadap LUTS dilakukan dengan uji statistik parametrik regresi linier menggunakan software $(\alpha<0,05)$. Penelitian dilakukan pada 13 pasien klinis BPH tanpa retensi, pada analisis bivariat dari hasil uji statistik antara IPP dengan LUTS didapatkan nilai $r=0,911$ dan nilai $p=0,000(p<0,05)$, sedangkan PVR dengan LUTS didapatkan nilai $r=0,922$ dan nilai $p=0,000(p<0,05)$, yang berarti bahwa terdapat hubungan yang positif dan signifikan antara IPP dengan LUTS serta PVR dengan LUTS. Pada analisis multivariat, nilai koefisien regresi IPP, $p=0,017(p<0,05)$, sedangkan nilai koefisien regresi PVR, $p=0,953$ ( $p>0,05)$, Sehingga IPP lebih baik untuk memprediksi beratnya LUTS dibandingkan dengan PVR. Berdasarkan hasil penelitian dapat disimpulkan bahwa, terdapat hubungan IPP dan PVR dengan LUTS pada pasien klinis BPH tanpa retensi.
\end{abstract}

Kata Kunci: benign prostatic hyperplasia, intravesical prostatic protrusion, post-void residual urine, lower urinary tract symptoms, bladder outlet obstruction.

\section{ABSTRACT}

Benign prostatic hyperplasia (BPH) is one of the benign tumors commonly found in men over 50 years of age who can cause lower urinary tract symptoms (LUTS). LUTS is a symptom of bladder outlet obstruction (BOO). Configuration of the prostate anatomy of intravesical prostatic protrusion (IPP) has been shown to have good correlation to cause BOO. A significant increase in the volume of post-void residual urine (PVR) is a frequent clinical manifestation in patients with BPH. Currently in RSDM, LUTS is still the standard in determining the management of BPH. Based on the above description, the researcher is interested in conducting research of IPP and PVR relationship with LUTS in clinical patient without BP retention. This is an analytic observational study with cross sectional design. The study sample was clinical BPH patients with no retention coming to the polyclinic during the study period, then transabdominal ultrasonography (TAUS) examination was performed to measure 
IPP and PVR volume as well as to assess the IPSS score to assess LUTS degree. Data analysis of the relationship between IPP and PVR to LUTS was done by statistical parametric test of linear regression using software ( $\alpha$ $<0,05$ ). The study was conducted on 13 clinical patients without retention, in bivariate analysis of statistical test results between IPP and LUTS obtained $r$ value $=0.911$ and $p=0,000(p<0,05)$, while PVR with LUTS obtained $r$ value $=0,922$ and value $p=0,000(p<0.05)$, which means that there is a positive and significant relationship between IPP with LUTS and PVR with LUTS. In the multivariate analysis, the regression coefficient value of IPP, $p=0.017$ ( $p<0.05$ ), while the regression coefficient value of PVR, $p=0.953$ ( $p>0.05$ ), so that IPP is better to predict the weight of LUTS compared with PVR. Based on the results of the study it can be concluded that, there is a relationship between IPP and PVR with LUTS in clinical patients BPH without retention.

Keywords: benign prostatic hyperplasia, intravesical prostatic protrusion, post-void residual urine, lower urinary tract symptoms, bladder outlet obstruction.

\section{PENDAHULUAN}

Benign prostatic hyperplasia (BPH) merupakan salah satu tumor jinak yang sering ditemukan pada pria. Penelitian ditemukan $20 \%$ BPH terdapat pada pria usia $41-50$ tahun, $50 \%$ BPH pada pria usia 51-60 tahun, $65 \%$ BPH pada pria usia $61-70$ tahun, $80 \% \mathrm{BPH}$ pada pria $71-80$ tahun, dan $90 \%$ BPH pada pria usia 81-90 tahun (Roehborn et al, 2015; Presti, 2008; Abrams et al, 2013).

Penggunaan istilah BPH berdasarkan histopatologi yaitu terjadinya peningkatan jumlah sel stroma dan sel epitel dari kelenjar prostat. Perubahan struktur prostat pada BPH meliputi perubahan volume dan histologi. Perubahan volume prostat terjadi bervariasi pada setiap umur. Beberapa penelitian cross sectional tentang volume prostat yang dibandingkan dengan usia dapat disimpulkan bahwa volume prostat meningkat menjadi $25 \mathrm{cc}$ pada pria usia 30 tahun dan 35-45 cc pada pria usia 70 tahun (Roehrborn et al, 2015).

Obstruksi kandung kemih pada pria usia lebih dari 50 tahun, terutama disebabkan oleh BPH. lower urinary tract symptoms (LUTS) adalah suatu kumpulan gejala dari bladder outlet obstruction (BOO) yang ditandai dengan gejala obstruktif dan iritatif. Pemeriksaan urodinamik adalah gold standar internasional untuk diagnosis $\mathrm{BOO}$, tetapi penggunaan rutin telah dibatasi karena bersifat invasif. Sampai saat ini tidak ada variabel objektif yang konsisten untuk menilai perbedaan derajat BOO sehingga bisa menentukan pengobatan yang paling tepat. Sebagian besar evaluasi telah difokuskan terutama pada gangguan fungsi berkemih bukan terhadap besarnya volume prostat. Penilaian subjektif keluhan LUTS adalah dengan menggunakan International Prostate Symptom Score (IPSS) yang mana ini terdiri dari tujuh pertanyaan dan satu pertanyaan quality of life (QOL) yang menyangkut kelompok gejala obstruktif dan iritatif dari BPH (Dmochowski, 2005; Presti, 2008; Lee A. et al, 2015).

Besarnya volume prostat, selama ini telah digunakan sebagai kriteria dalam mendiagnosis BPH. Beberapa penelitian menyatakan bahwa volume prostat dapat digunakan untuk memperkirakan hasil terapi dan kepentingan pengelolaan pembedahan seperti penentuan jenis operasinya. Sehingga penentuan volume prostat dapat berguna sebagai rencana terapi pembedahan dan monitoring hasil terapi BPH (Terris, 2015).

Penentuan volume prostat dapat dilakukan dengan pemeriksaan colok dubur, ultrosonography (USG) secara transabdominal ultrasonography (TAUS) maupun transrectal ultrasonography (TRUS), magnetic resonance imaging (MRI), dan computed tomography (CT). Volume prostat merupakan petunjuk objektif untuk $\mathrm{BPH}$, tetapi besarnya volume prostat tidak selalu berhubungan dengan beratnya LUTS dan parameter fisiologi lain seperti aliran urin dan post-void residual urine (PVR). Beberapa pemeriksaan telah digunakan dalam mengevaluasi risiko terjadinya BOO termasuk uroflowmetry, post-void residual urine (PVR) atau volume residual urine, prostate specific antigen (PSA) dan intravesical prostatic protrusion (IPP) (Reis et al, 2008; Hoo et al, 2014; Lee et al, 2015).

Intravesical prostatic protrusion adalah suatu penonjolan prostat mulai dari leher buli-buli ke dalam rongga buli-buli yang mengakibatkan mekanisme ball valve di leher buli-buli sehingga mengganggu aliran urin yang melewati leher bulibuli. Konfigurasi anatomi prostat dalam bentuk IPP telah terbukti memiliki korelasi yang baik untuk menyebabkan BOO. Pemeriksaan dengan TAUS bisa digunakan untuk membuktikan derajat 
IPP. Derajat IPP dibagi menjadi derajat I ukuran $<5 \mathrm{~mm}$, derajat II ukuran 5-10 mm, derajat III $>10$ $\mathrm{mm}$ (Lee et al, 2010).

Volume residual urine atau PVR adalah sisa urin yang tertinggal di dalam buli-buli setelah miksi. Peningkatan signifikan volume PVR adalah manifestasi klinis yang sering terdapat pada pasien dengan BPH. Kondisi BOO yang tidak diobati akan menyebabkan kompensasi dari bulibuli berupa hipertropi dari otot-otot detrusor dan peningkatan kontraktilitas untuk mempertahankan pengosongan efektif buli-buli meskipun terjadi obstruksi. Volume PVR akan meningkat sebagai akibat dari ketidakseimbangan relatif antara kontraktilitas buli-buli dan peningkatan resistensi saluran keluar terutama pada leher buli-buli sehingga yang berujung pada retensi urin kronis (Bosch, 2005; Elmissiry et al, 2014).

Penelitian yang dilakukan oleh Lee et al (2015) pada 114 pasien usia di atas 50 di Singapura, disimpulkan bahwa IPP adalah prediktor yang baik dan lebih tepat untuk memprediksi terjadinya BOO dibandingkan dengan variabel lainnya. Penelitian lain menyebutkan bahwa derajat IPP dapat memprediksi terjadinya gangguan $\mathrm{BOO}$ (Lee et al, 2015).

Di RS X Surakarta pengukuran derajat IPP dan volume PVR belum menjadi hal yang umum untuk dicermati sebagai prediktor terjadinya $\mathrm{BOO}$ pada pasien klinis BPH tanpa retensi. Sehingga saat ini LUTS masih menjadi standar dalam menentukan tata laksana BPH. Berdasarkan uraian di atas peneliti tertarik untuk melakukan penelitian hubungan IPP dan PVR dengan LUTS pada pasien klinis BPH tanpa retensi.

\section{METODE}

Penelitian ini merupakan studi observasional analitik dengan desain cross sectional untuk mempelajari hubungan IPP dan PVR dengan LUTS pada pasien klinis BPH tanpa retensi. Sampel penelitian adalah pasien usia $>50$ tahun dengan klinis BPH tanpa retensi yang datang ke poliklinik Urologi dan Poliklinik Geriatri RS X
Surakarta selama periode penelitian (bulan Maret 2017-Mei 2017).

Kemudian pasien dilakukan pemeriksaan transabdominal ultrasonography (TAUS) di Instalasi Radiologi RS X Surakarta untuk mengukur IPP dan volume PVR serta menilai skor IPSS untuk menilai derajat LUTS. Teknik pengambilan sampel pada penelitian ini adalah consecutive sampling, yaitu semua dari populasi yang datang berurutan dan memenuhi kriteria pemilihan dimasukkan dalam penelitian sampai jumlah subjek yang diperlukan terpenuhi.

Kriteria Inklusi, yaitu: pasien pria, usia $>50$ tahun yang mempunyai gejala LUTS yang telah didiagnosis dengan klinis BPH tanpa retensi, dan bersedia mengisi serta menandatangani formulir pernyataan persetujuan penelitian. Kriteria eksklusi, yaitu: Pasien LUTS dengan struktur uretra, infeksi saluran kemih (ISK), prostatitis, keganasan buli-buli, klinis curiga keganasan prostat, dan batu saluran kemih. Pasien klinis $\mathrm{BPH}$ yang sudah mengalami retensi urin dan gagal ginjal. Pasien dengan DM (diabates mellitus) dan gangguan penyakit neurologis. Pasien sedang dalam penggunaan obat antikolinergik dan antidepressant. Pasien pernah terapi medikamentosa BPH sebelumnya. Pasien pernah menjalani operasi BPH sebelumnya.

Analisis data hubungan antara IPP dan PVR dengan LUTS pada pasien klinis BPH tanpa retensi dilakukan dengan uji statistik parametrik regresi linier menggunakan software $(\alpha<0,05)$.

\section{HASIL DAN PEMBAHASAN}

Penelitian ini dilakukan pada 13 pasien klinis BPH tanpa retensi yang datang di Poliklinik Urologi dan Geriatri RS X Surakarta selama 3 bulan, yaitu bulan Maret hingga bulan Mei 2017.

Karateristik dasar subjek penelitian pasien klinis BPH tanpa retensi meliputi umur, jenis kelamin, IPP, PVR, dan LUTS yang diukur melalui IPSS. Berdasarkan hasil penelitian pada 13 sampel didapatkan hasil gambaran data dasar subjek penelitian adalah sebagai berikut.

Tabel 1 Karateristik subjek penelitian

\begin{tabular}{lcccc}
\hline \multicolumn{1}{c}{ Variabel } & Minimum & Maximum & Mean & Std. Deviation \\
\hline Umur (thn) & 61 & 89 & 72.38 & 7.81 \\
IPP (mm) & 2.6 & 21.3 & 9.06 & 4.99 \\
PVR (ml) & 3.44 & 66.9 & 18.32 & 18.05
\end{tabular}


LUTS

\begin{tabular}{lll} 
Ringan f $(\%)$ & 1 & $(7,7 \%)$ \\
Sedang f $(\%)$ & 7 & $(53,8 \%)$ \\
Berat f $(\%)$ & 5 & $(38,5 \%)$ \\
\hline
\end{tabular}

Berdasarkan tabel 1 diketahui bahwa pasien klinis BPH tanpa retensi dengan umur minimum 61 tahun dan maksimum 89 tahun dengan ratarata umur $72,38 \pm 7,81$ tahun. Pada penelitian ini semua pasien klinis BPH tanpa retensi berjenis kelamin laki-laki. Kadar IPP minimum sebesar 2,6 $\mathrm{mm}$ dan maksimum sebesar 21,3mm dengan rata-rata IPP 9,06+4,99 $\mathrm{mm}$. Kadar volume PVR minimum 3,44 $\mathrm{ml}$ dan maksimum $66,9 \mathrm{ml}$ dengan rata-rata volume PVR sebesar 18,32 $\pm 18,05 \mathrm{ml}$. Nilai IPSS minimum 7 dan maksimum 27 dengan rata-rata nilai IPSS sebesar 17,38+5,69. Nilai IPSS jika dihubungkan dengan derajat LUTS maka didapatkan mayoritas pasien dalam kategori sedang yaitu 7 pasien $(53,8 \%)$, sedangkan minoritas dalam kategori ringan yaitu ada 1 pasien $(7,7 \%)$.

\section{a. Pasien dengan LUTS Ringan (IPSS: 7)}
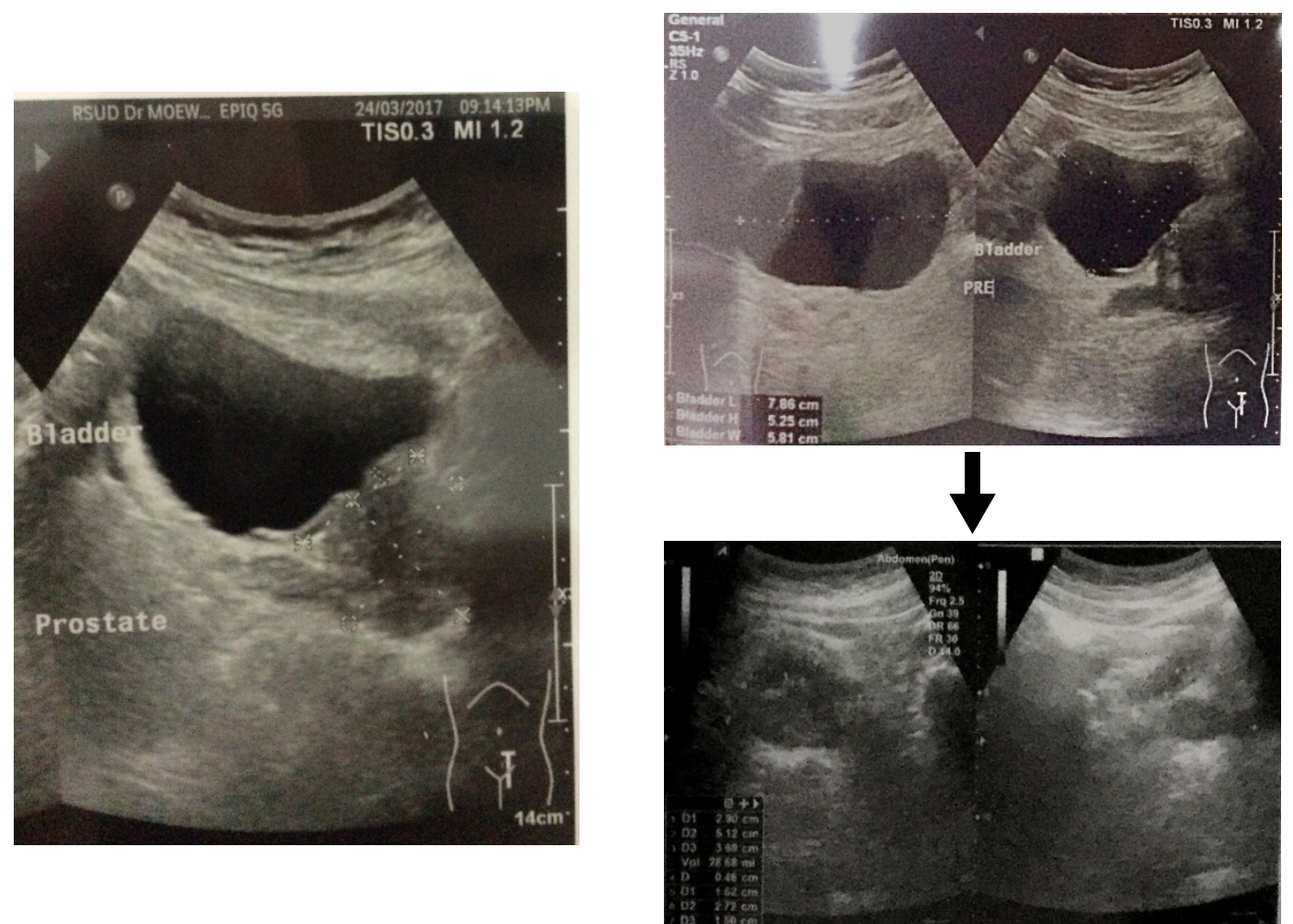

Gambar 1 Pasien dengan LUTS Ringan, didapatkan Pengukuran IPP: 2,6 mm (Derajat I: $<5 \mathrm{~mm}$ ), dengan volume urine pre-miksi: 155,53 ml, volume urine post miksi didapatkan PVR sebesar 4,53 ml 
b. Pasien dengan LUTS Sedang (IPSS: 18)
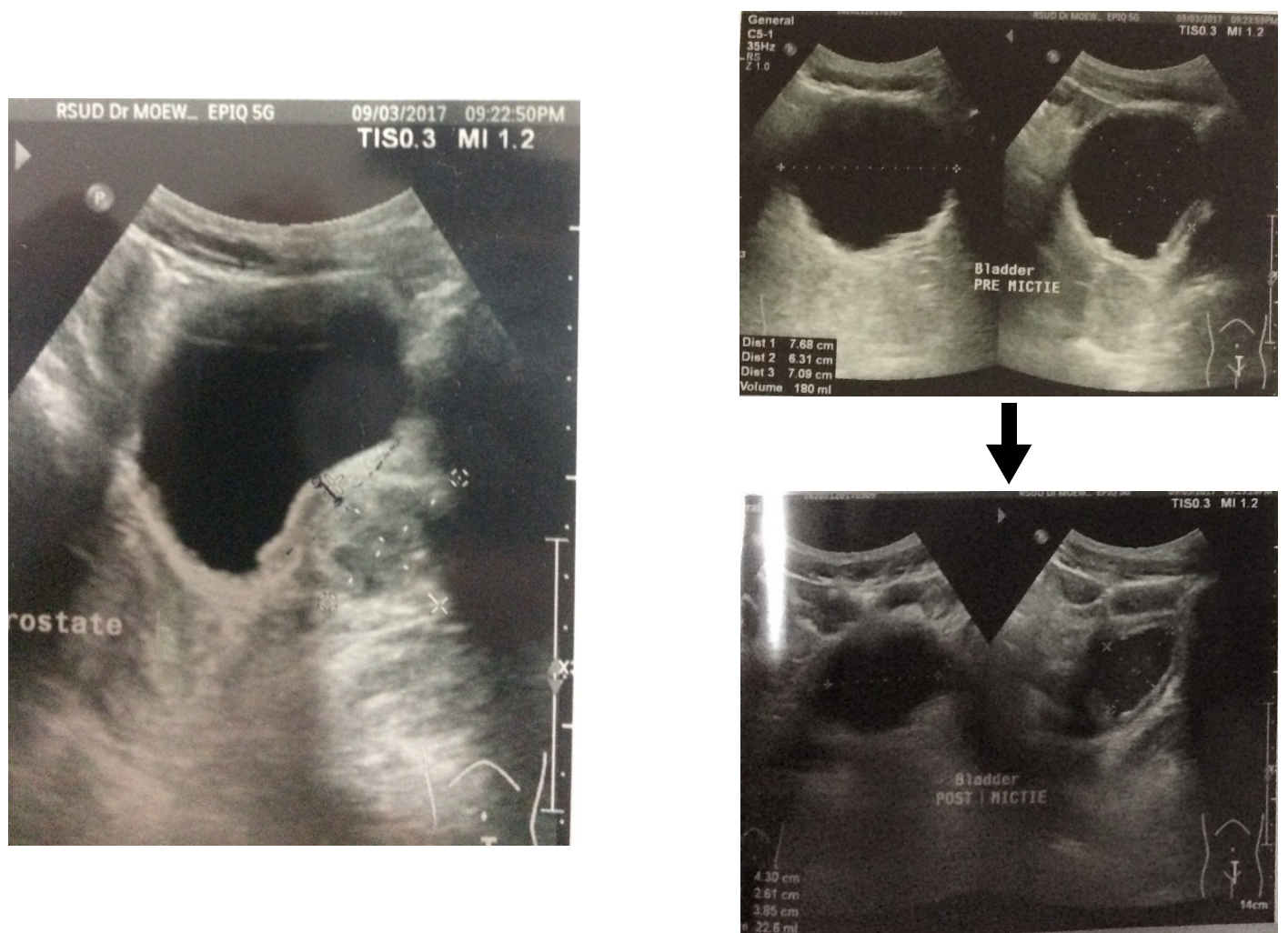

Gambar 2 Pasien dengan LUTS Sedang, didapatkan Pengukuran IPP: 8,2 mm (Derajat II: 5-10mm), dengan volume urine pre-miksi: $180 \mathrm{ml}$, volume urine post miksi didapatkan PVR sebesar 22,6 ml.

c. Pasien dengan LUTS Berat (IPSS: 27)
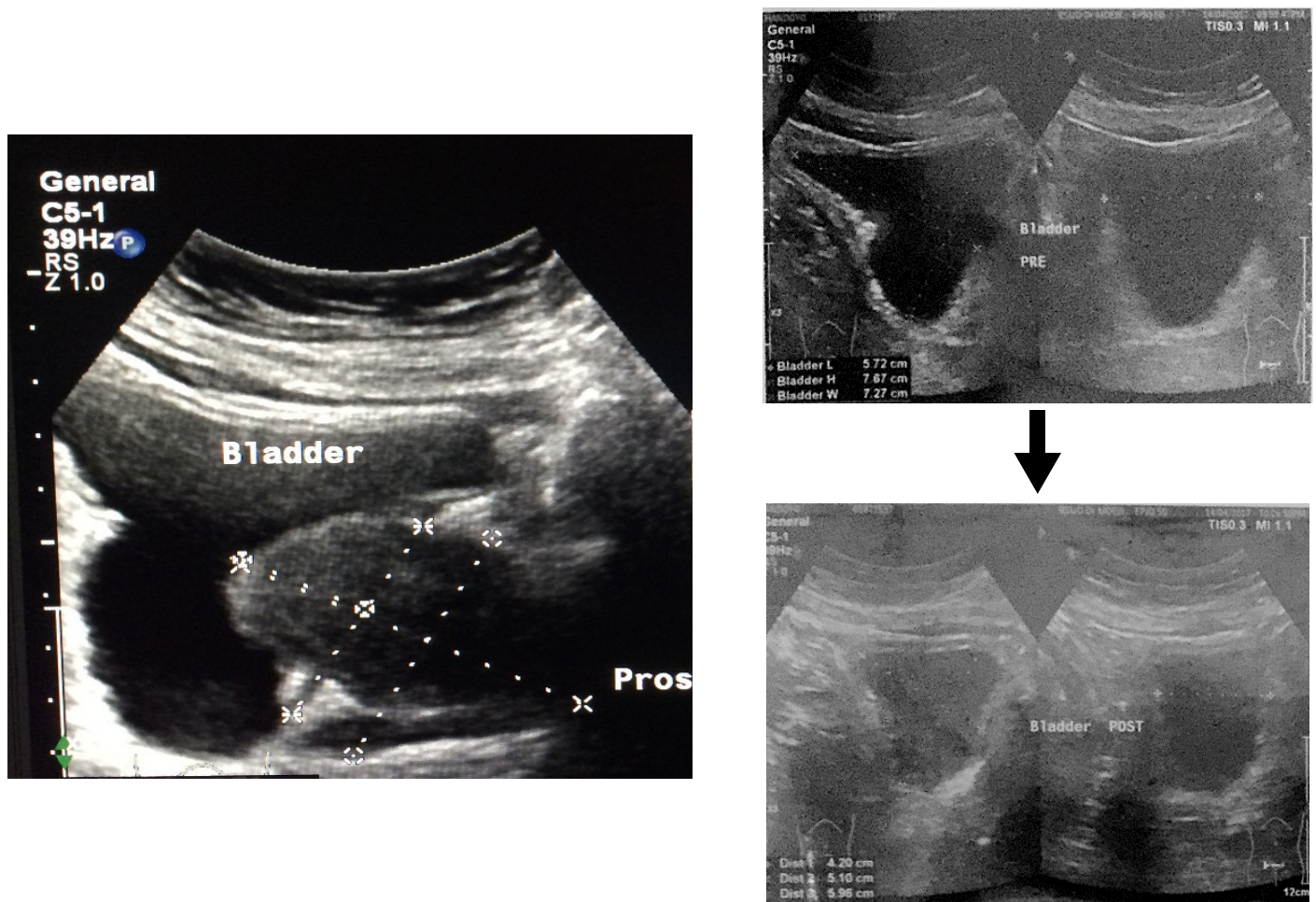

Gambar 3 Pasien dengan LUTS Berat, didapatkan Pengukuran IPP: 21,3 mm (Derajat III: >10mm), dengan volume urine pre-miksi: $167 \mathrm{ml}$, volume urine post miksi didapatkan PVR sebesar 66,9 ml. 
Tujuan penelitian ini adalah untuk mengetahui hubungan IPP dan PVR dengan LUTS pada pasien klinis BPH tanpa retensi. Sebelumnya dilakukan uji normalitas data terlebih dahulu untuk mengetahui sebaran distribusi data. Pada penelitian ini digunakan uji Shapiro-Wilk, hasil uji normalitas didapatkan nilai $\mathrm{p}>0,05$ maka distribusi data dinyatakan memenuhi asumsi normalitas, maka uji koeralisi dalam penelitian ini menggunakan uji Pearson product moment. Jika nilai $\mathrm{p}<0,05$ maka distribusi data dinyatakan tidak memenuhi asumsi normalitas maka uji statistik dalam penelitian ini menggunakan uji Spearman's rank.

Tabel 2 Hubungan bivariat antara intravesical prostatic protrusion dan post-void residual urine dengan lower urinary tract symptoms

\begin{tabular}{ccc}
\hline \multirow{2}{*}{ Variabel } & \multicolumn{2}{c}{ IPSS } \\
\cline { 2 - 3 } & $\mathbf{R}$ & $\mathbf{P}$ \\
IPP $^{\mathrm{a}}$ & 0,911 & $0,000^{* *}$ \\
PVR $^{\mathrm{b}}$ & 0,922 & $0,000^{* *}$ \\
\hline
\end{tabular}

Ket:

a. Distribusi data normal uji Pearson Product Moment

b. Distribusi data tidak normal uji Spearman Rank

** Signifikan pada $\alpha=1 \%$

Hasil uji statistik antara IPP dengan LUTS didapatkan nilai $\mathrm{r}=0,911$ dan nilai $\mathrm{p}=0,000$ $(\mathrm{p}<0,05)$, yang berarti bahwa terdapat hubungan yang positif dan signifikan antara IPP dengan LUTS, dengan kekuatan hubungan dalam kategori sangat kuat, jadi ada kecenderungan semakin tinggi kadar IPP maka semakin tinggi pula LUTS.

Hasil uji statistik antara PVR dengan LUTS didapatkan nilai $\mathrm{r}=0,922$ dan nilai $\mathrm{p}=0,000$ $(p<0,05)$, yang berarti bahwa terdapat terdapat hubungan yang positif dan signifikan antara PVR dengan LUTS, dengan kekuatan hubungan dalam kategori sangat kuat, jadi ada kecenderungan semakin tinggi kadar PVR maka semakin tinggi pula LUTS.

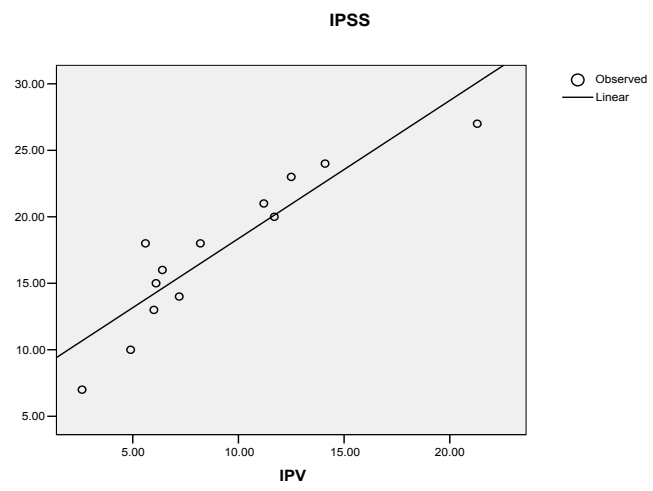

Gambar 4 Scatter plot hubungan IPP dengan IPSS (LUTS)

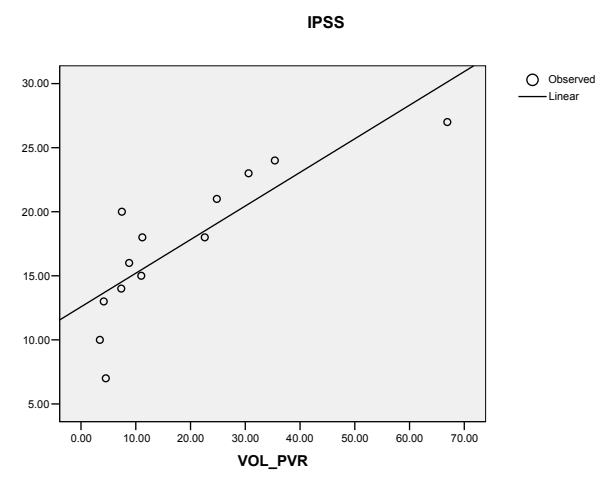

Gambar 5 Scatter plot hubungan PVR dengan IPSS (LUTS)

Berdasarkan tabel 3 diketahui bahwa hubungan IPP dan PVR dengan LUTS yang dinilai dengan IPSS mendapatkan nilai R Square $=0,829$, yang berarti bahwa variansi IPSS dapat dijelaskan oleh IPP dan PVR sebesar 82,9\%, sisanya 17,1\% dijelaskan faktor lain diluar model. Nilai $\mathrm{p}=0,000$ $(p<0,001)$ yang berarti terdapat hubungan yang signifikan IPP dan PVR dengan LUTS secara simultan.

Tabel 3 Uji regresi hubungan intravesical prostatic protrusion dan post-void residual urine dengan lower urinary tract symptoms

\begin{tabular}{lcc}
\hline \multirow{2}{*}{ Variabel } & \multicolumn{2}{c}{ IPSS/LUTS } \\
\cline { 2 - 3 } Constant & 7,899 & Prob. $\mathbf{~}$ \\
IPP & 1,059 & $0,017 *$ \\
PVR & $-0,006$ & 0,953 \\
\hline $\mathrm{R}^{2}$ & 0,829 & \\
Prob. F & $0,000 * *$ \\
\hline Ket: & $*$ Signifikan pada $\alpha=5 \%$ & \\
& $* *$ Signifikan pada $\alpha=1 \%$ &
\end{tabular}


Nilai koefisien regresi (B) IPP sebesar 1,059 , yang berarti bahwa setiap meningkatnya IPP sebesar 10,0\%, maka akan meningkatkan IPSS sebesar $10,59 \%$. Nilai $p=0,017(p<0,05)$, yang berarti ada pengaruh yang signifikan antara IPP terhadap IPSS atau LUTS.

Nilai koefisien regresi (B) PVR sebesar $-0,006$, yang berarti bahwa setiap meningkatnya PVR sebesar $10,0 \%$, maka akan menurunkan IPSS sebesar $0,06 \%$. Nilai $\mathrm{p}=0,953(\mathrm{p}>0,05)$, yang berarti tidak ada pengaruh yang signifikan antara PVR terhadap IPSS atau LUTS.

Berdasarkan uraian diatas maka variabel yang dominan mempengaruhi LUTS adalah IPP. Sehingga IPP lebih baik untuk memprediksi beratnya LUTS dibandingkan dengan PVR.

Lower urinary tract symptoms (LUTS) pada pria usia lebih dari 50 tahun, terutama disebabkan oleh BPH. Lower urinary tract symptoms (LUTS) adalah suatu kumpulan gejala dari bladder outlet obstruction (BOO) yang ditandai dengan gejala obstruktif dan iritatif. Beberapa pemeriksaan telah digunakan dalam mengevaluasi risiko terjadinya BOO termasuk uroflowmetry, post-void residual urine (PVR) atau volume residual urin, prostate specific antigen (PSA) dan Intravesical prostatic protrusion (IPP) (Reis et al, 2008; Hoo et al, 2014; Lee et al, 2015; Roehrborn et al, 2015).

Dalam penelitian ini peneliti ingin mengetahui hubungan hubungan IPP dan PVR dengan LUTS pada pasien klinis BPH tanpa retensi. Untuk mencapai tujuan tersebut telah dilakukan penelitian observasional analitik. Pengujian hipotesis pada penelitian ini dilakukan menggunakan uji Spearman's rank correlation dengan uji statistik parametrik regresi linier.

Berdasarkan statistik pada penelitian ini didapatkan 13 pasien BPH tanpa retensi dengan umur minimum 61 tahun dan maksimum 89 tahun dengan rata-rata umur $72,38 \pm 7,81$ tahun. Semua sampel pasien klinis BPH tanpa retensi berjenis kelamin laki-laki. Kadar IPP minimum sebesar 2,6 $\mathrm{mm}$ dan maksimum sebesar 21,3mm dengan rata-rata IPP 9,06 \pm 4,99 mm. Kadar volume PVR minimum 3,44 $\mathrm{ml}$ dan maksimum $66,9 \mathrm{ml}$ dengan rata-rata volume PVR sebesar 18,32 $\pm 18,05 \mathrm{ml}$. Nilai IPSS minimum 7 dan maksimum 27 dengan rata-rata nilai IPSS sebesar 17,38 \pm 5,6 9. Nilai IPSS jika dihubungkan dengan derajat LUTS maka didapatkan mayoritas pasien dalam kategori sedang yaitu 7 pasien $(53,8 \%)$, sedangkan minoritas dalam kategori ringan yaitu ada 1 pasien $(7,7 \%)$.

Dari hasil ini didapatkan bahwa angka kejadian BPH semakin meningkat sesuai dengan peningkatan usia, ini sesuai dengan penelitian pada autopsi ditemukan 20\% BPH terdapat pada pria usia $41-50$ tahun, $50 \%$ BPH pada pria usia 51-60 tahun, 65\% BPH pada pria usia $61-70$ tahun, $80 \%$ BPH pada pria $71-80$ tahun dan $90 \%$ BPH pada pria usia 81-90 tahun (Roehborn et al, 2015; Presti, 2008; Abrams et al, 2013).

Pada penelitian ini menunjukkan terdapat kecenderungan semakin tinggi kadar IPP maka semakin tinggi pula LUTS. Hal ini dapat dilihat dari hubungan IPP dengan LUTS didapatkan nilai $\mathrm{r}=0,911$ dan nilai $\mathrm{p}=0,000(\mathrm{p}<0,05)$, yang berarti bahwa terdapat terdapat hubungan yang positif dan signifikan antara IPP dengan LUTS, dengan kekuatan hubungan dalam kategori sangat kuat.

Seperti yang diuraikan pada penelitian sebelumnya, gejala klinis BPH merupakan akibat yang komplek dari kondisi muskulus detrusor dan adanya tahanan di leher buli-buli. Tahanan leher buli-buli oleh karena penonjolan prostat ke dalam buli-buli yang disebut IPP bisa menyebabkan terjadinya mekanisme ball valve di bladder outlet sehingga mengganggu aliran urin yang melewati leher buli-buli yang bisa diukur dengan uroflowmetry, dan dapat mempengaruhi penilaian skor IPSS (Lee et al, 2010).

Pada penelitian ini hubungan PVR dengan LUTS didapatkan nilai $r=0,922$ dan nilai $p=0,000$ $(p<0,05)$, yang berarti bahwa terdapat terdapat hubungan yang positif dan signifikan antara PVR dengan LUTS, dengan kekuatan hubungan dalam kategori sangat kuat, jadi ada kecenderungan semakin tinggi kadar PVR maka semakin tinggi pula LUTS.

Semua pria normal mempunyai PVR tidak lebih dari $12 \mathrm{ml}$. Peningkatan signifikan volume PVR adalah manifestasi klinis yang sering terdapat pada pasien dengan BPH. Pengukuran volume residual urin melalui kateterisasi lebih akurat dibandingkan dengan USG, tetapi lebih bersifat invasif. Pengukuran dengan cara apapun, volume residual urin mempunyai variasi individual yang cukup tinggi. Variasi perbedaan volume residual urine ini tampak nyata pada residual urin yang cukup banyak $(>150 \mathrm{ml})$, sedangkan volume residual urin yang tidak terlalu banyak $(<120 \mathrm{ml})$ hasil pengukuran dari 
waktu ke waktu hampir sama (Amole et al, 2004; Elmissiry et al, 2014).

Pada penelitian ini ada satu pasien yang telah dilakukan inform consent kemudian dilakukan pemeriksaan PVR melalui kateterisasi dan TAUS untuk dibandingkan hasilnya. Didapatkan PVR yang diukur melalui TAUS sebesar $66,9 \mathrm{ml}$ dan melalui kateterisasi sebesar $70 \mathrm{ml}$. Ternyata tidak terdapat perbedaan yang signifikan antara volume residual urin yang diukur melalui TAUS dan kateterisasi pada pasien ini.

Pada penelitian ini 13 sampel pasien BPH tanpa retensi dilakukan pemeriksaan TAUS oleh semua dokter ahli radiologi dengan bulibuli dalam keadaan distensi (150-300 $\mathrm{ml}$ urin). Derajat IPP diukur tegak lurus dari ujung protrusi prostat di dalam buli-buli ke dasar buli-buli pada penampang sagital dari TAUS. Kemudian sesaat setelah pasien miksi dilakukan pengukuran volume PVR. Penilaian derajat LUTS dengan skor IPSS pada sampel penelitian dapat dilakukan sebelum ataupun setelah pemeriksaan TAUS.

Hasil penelitian menunjukkan bahwa variabel yang dominan mempengaruhi LUTS adalah IPP. Sehingga IPP lebih baik sebagai prediktor dibandingkan dengan PVR. Dimana setiap meningkatnya IPP sebesar 10,0\%, maka akan meningkatkan IPSS sebesar 10,59\%, dimana IPSS sebagai alat ukur untuk menilai LUTS. Sehingga ini membuktikan, semakin tinggi derajat IPP semakin tinggi pula derajat LUTS.

Hasil penelitian ini sejalan dengan penelitian yang dilakukan oleh Chia S.J. et al (2002) pada 125 sampel di Singapura, didapatkan hasil bahwa IPP adalah prediktor BOO yang lebih baik secara statistik $(\mathrm{P}<0,001)$ dan lebih dapat diandalkan dibandingkan dengan variabel lain seperti volume prostat, Qmax, dan PVR. Dari jumlah tersebut, 94 sampel dgn IPP derajat III dan 30 sampel dengan IPP derajat I-II. Tujuh puluh lima pasien memiliki indeks $\mathrm{BOO}<40$; di mana 69 sampel dengan IPP derajat I-II dan 6 sampel dengan IPP derajat III. Sehingga IPP derajat III memiliki indeks BOO yang lebih tinggi daripada derajat I-II $(\mathrm{P}<0,001)$ (Chia S.J.et al, 2002). Penelitian lain yang dilakukan di korea tahun 2007 juga menyebutkan bahwa derajat IPP dapat memprediksi terjadinya gangguan BOO (Jeong et al., 2007).

Pada penelitian yang dilakukan Lim et al (2006) di Singapura pada 114 pasien usia di atas 50 tahun didapatkan bahwa volume prostat, IPP, dan PSA menunjukkan korelasi paralel. Meski ketiga variabel tersebut memiliki korelasi yang baik dengan indeks BOO, namun IPP adalah yang terbaik. Koefisien Spearman's rank correlation masing-masing adalah 0,314; 0,408; dan 0,507 untuk volume prostat, PSA, dan IPP. Dengan menggunakan receiver-operator characteristic curves area di bawah kurva untuk volume prostat, PSA, dan IPP masing-masing adalah 0,637; 0,703; dan 0,772 . Nilai prediktif positif volume prostat, PSA dan IPP masing-masing adalah $65 \%, 68 \%$, dan $72 \%$. Dengan menggunakan model regresi nominal, IPP tetap merupakan indeks independen yang paling signifikan untuk menentukan BOO (Lim et al, 2006).

Lee et al (2015) dalam penelitian di Singapura pada 61 pasien yang memiliki aliran urin yang baik (indeks BOO> 40 dan Qmax $>12,0$ $\mathrm{ml} / \mathrm{s}$ ) didapatkan usia rata-rata, volume prostat dan Qmax adalah 66 tahun, 32,9 mm3 dan 14,5 $\mathrm{mL} / \mathrm{s}$. Sebanyak 14 pasien $(23,0 \%)$ memiliki BOO dan distribusi IPP mereka adalah sebagai berikut: derajat I 0 pasien $(0 \%)$, derajat II sebanyak 6 pasien $(27,3 \%)$, dan derajat III sebanyak 8 pasien $(42,1$ $\%)$. Sensitivitas pada IPP derajat II/II untuk BOO adalah 100\% sedangkan spesifitas IPP derajat III adalah 76,6\%. Area under-curve (AUC) untuk IPP lebih besar dari pada volume prostat $(0,757$ vs 0,696). Pada penelitian tersebut disimpulkan bahwa IPP sebagai parameter yang bisa digunakan untuk memprediksi tejadinya risiko BOO, bahkan pada pasien dengan aliran urin yang baik (Lee et $a l, 2015)$.

Nilai koefisien regresi (B) PVR sebesar $-0,006$, yang berarti bahwa setiap meningkatnya PVR sebesar 10,0\%, maka akan menurunkan IPSS sebesar $0,06 \%$. Nilai $p=0,953 \quad(p>0,05)$, yang berarti tidak ada pengaruh yang signifikan antara PVR terhadap IPSS atau LUTS.

Dahulu para ahli urologi beranggapan bahwa volume residual urin yang meningkat menandakan adanya obstruksi, sehingga perlu dilakukan pembedahan, namun ternyata peningkatan volume residual urin tidak selalu menunjukkan beratnya gangguan pancaran urin atau beratnya obstruksi. Namun bagaimanapun adanya residu urin menunjukkan telah terjadi gangguan miksi (Mochtar et al, 2015).

Dengan demikian baik IPP maupun PVR berhubungan positif dengan Skor IPSS atau LUTS. Akan tetapi IPP adalah prediktor yang 
lebih baik dan tepat untuk memprediksi beratnya LUTS dibandingkan dengan PVR.

\section{SIMPULAN}

Berdasarkan hasil penelitian yang dilakukan pada 13 pasien dapat disimpulkan bahwa, ada hubungan IPP dan PVR dengan LUTS pada pasien klinis BPH tanpa retensi. Dari hasil penelitian ini diharapkan pasien $\mathrm{BPH}$ tanpa retensi yang akan dilakukan pemeriksaan penunjang USG urologi sebaiknya dapat ditambahkan penilaian untuk IPP dan PVR, sehingga IPP dan PVR bisa dipertimbangkan sebagai sarana diagnostik dan evaluasi pada pasien BPH. Diperlukan penelitian lebih lanjut agar IPP dan PVR dapat digunakan sebagai dasar terapi pada pasien BPH.

\section{DAFTAR PUSTAKA}

Abrams P., Chapple C., Khoury S., Roehrborn C., \& De la Rosette J. 2013. Evaluation and Treatment of Lower Urinary Tract Symptoms in Older Men. Jurnal of Urology, 189(1), 93-101.

Amole A.O., Kuranga S.A., \& Oyejola B.A. 2004. Sonographic Assessment of Postvoid Residual Urine Volumes in Patients with Benign Prostatic Hyperplasia. Journal of the National Medical Association, 96(2), 234-239.

Bosch R.J., 2005. Post-void Residual Urine in the Evaluation of Men with Benign Prostatic Hyperplasia. World Journal of Urology, 13(1), 17-20.

Chia S.J., Heng C.T., Chan S.P., \& Foo K.T. 2002. Correlation of Intravesical Prostatic Protrusion with Bladder Outlet Obstruction. Jurnal of Urology, 91, 371-374.

Dmochowski R.R. 2005. Bladder Outlet Obstruction: Etiology and Evaluation. Reviews in Urology, 7 (6), 3-13.

Elmissiry M.M., Ali A.G., Abdulfotooh A., Moussa A.A., \& Ali G.A. 2014. Factors Determining the Amount of Residual Urine in Men with Bladder Outlet Obstruction: Could it be a Predictor of Bladder Contractility?. Arab Journal of Urology, 12, 214-218.

Hoo K.N., Ayob M.A., Salim M.I.,Abduljabbar H.N., \& Supriyanto E. 2014. Prostat Volume Measurement Using Transabdominal Ultrasound Scanning. Advances in Environment Biotechnology and Biomedicine, 4, 336-341

Jeong S.J., Park C.S., Hwang I.S., Kwak C., Cho J.Y., Kim S.W., et al. 2007. Can Intravesical Prostatic Protrusion Predict Bladder Outlet Obstruction?. Korean Journal of Urology, 53(7), 478-482.

Lee A., Lee H.J., Lim K.B., Huang H.H., Ho H., \& Foo K.T. 2015. Can Intravesical Prostatic Protrusion Predict Bladder Outlet Obstruction even in Men with Good Flow?. Asian Journal of Urology, 3, 39-43.

Lee L.S., Sim H.G., Lim K.B., Wang D., \& Foo K.T. 2010. Intravesical Prostatic Protrusion Predicts Clinical Progression of Benign Prostatic Enlargement in Patients receiving Medical Treatment. International Journal of Urology, 17, 69-74.

Lim K.B., Ho H., Foo K.T., Wong M.Y., Fook-Chong S. 2006. Comparison of Intravesical Prostatic Protrusion, Prostate Volume and Serum Prostatic Specific Antigen in the Evaluation of Bladder Outlet Obstruction. International Journal of Urology, 13(12), 1509-13.

Mochtar A.C., Umbas R., Soebadi D.M., Rasyid N., Noegroho B.S., Poernomo B.B., et al. 2015. Panduan Penatalaksanaan Klinis Benign Prostatic Hyperplasia (BPH). Retrieved from Ikatan Ahli Urologi Indonesia (IAUI) website: http://www.iaui.or.id.

Presti J.C. 2008. Neoplasms of the prostate gland. In Tanagho E.A., \& McAninch J.W. (Eds). Smith's General Urology 1 $7^{\text {th }}$ ed. (pp.367-385). New York: Lange Medical Books, Mc Graw-Hill.

Reis O.L., Barreiro G.C., Baracat J., Prudente A., \& D’Ancona C. 2008. Intravesical Protrusion of the Prostate as a Predictive Method of Bladder Outlet Obstruction. International Brazil Journal of Urology, 34 (5), 627-637. 
Roehrborn C.G., \& McConnell J.D. 2015. Etiology, Pathophysiology, Epidemiology, and Natural History of Benign Prostatic Hyperplasia. In Walsh P.C., Retik A.B., Vaughan E.D Jr., Wein A.J., et al (Eds). Campbell-Walsh Urology $11^{\text {th }}$ ed. (pp.1297-1336). Philadelphia: Elsevier.

Terris M.K. 2015. Ultrasonography and biopsy of the prostate. In Walsh P.C., Retik A.B., Vaughan E.D Jr., Wein A.J., et al (Eds). Campbell-Walsh Urology $11^{\text {th }}$ ed. (pp.3038-3054). Philadelphia: Elsevier. 